\title{
NASSIN KAPSAMADIĞI MESELELER VE ŞER'Î HÜKÜM TANIMI
}

\author{
Ahmet Selman BAKTI*
}

\section{Makale Bilgisi}

Makale Türü: Araştırma Makalesi, Geliş Tarihi: 30 Aralık 2020, Kabul Tarihi: 26 Şubat 2021, Yayın Tarihi: 31 Mart 2021, Atıf: Bakt1, Ahmet Selman. "Nassın Kapsamadığı Meseleler Ve Şer'î Hüküm Tanımı". Dinbilimleri Akademik Araştırma Dergisi 21/1 (Mart 2021): 179-207.

https://doi.org/10.33415/daad.850629

Article Information

Article Types: Research Article, Received: 30 December 2020, Accepted: 26 February 2021, Published: 31 March 2021, Cite as: Bakt1, Ahmet Selman. "Things Whose Provisions Are Not Found in The Qur'an And Sunnah And The Definition of The Shari'a's Judgment". Journal of Academic Research in Religious Sciences 21/1 (March 2021): 179-207.

https://doi.org/10.33415/daad.850629

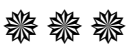

Öz

Meydana gelen bütün meselelerin hükmü naslarda bulunmadığından fukaha şerî̀ hükme ulaşmak için çeşitli usulî enstrümanlar geliştirmiştir. Fakat bunlarla hüküm çıkarılmasının meşruiyeti ve kullanımıyla ilgili şartlar üzerinde ittifak sağlanamamıştır. Aslında mesele varılan hükmü neyin şerîi kıldı̆̆ı yani şerî hükmün tanımıyla ilgilidir. Zira nassın kapsamadığı meselede varılan yargı şerî hüküm tanımınca onanmayabilir. Hükmü hitaba eşitleyerek hüsün-kubuhun aklîliğini reddettiğinden yaygın tanımın aksi görüştekilerce esas alınması bir çelişki olacaktır. Dolayısıyla hüküm hüsün-kubuhun aklîliğini savunanları bu çelişkiden kurtaracak şekilde yeniden tanımlanmalıdır. Nass-vakıa arasındaki makasın gittikçe açıldığı günümüzde tanım, hükmün doğru tespiti ve nasların yerli yerinde kullanımına da katkı sağlamalıdır.

Anahtar Kelimeler: Akıl, Hüsün-kubuh, Dinî bildirim.

Doktor Öğretim Üyesi, Sakarya Üniversitesi İlahiyat Fakültesi Temel İslam Bilimleri İslam Hukuku, selman_bkt@hotmail.com, Orcid Id: https://orcid.org/0000-00020222-3051 
Things Whose Provisions Are Not Found in The Qur'an And Sunnah And The Definition of The Shari'a's Judgment

Abstract

Since the verdict of all the issues that occurred isn't found in the Qur'an, fuqaha has developed various procedural instruments to arrive at the Shari'a rulling. However, there was no consensus on the legitimacy of making judgments using them. In fact, the issue is about the definition of the religious judgment. Thus, the judgment reached on issues that are not included in al-Kitaab and as-Sunnah may not be suitable for the definition of religious judgment. Since it rejects the rationality of al-husn-al-qubh by equating the judgment with the divine address, it would be a contradiction that the common definition is taken as a basis by those of the opposite view. Therefore, the Shari'a rulling should be redefined in a way to save those who claim that al-husn-al-qubh is rational from this contradiction. The definition should contribute to the correct definition of judgment and the use of the Nass in their right place, in today's world where the gap between Nass and reality is widening.

Keywords: Mind, al-Husn-al-Qubh, Divine Revelation.

\section{Giriş}

Peygamberler tarihi, çağlar boyunca Şâri'in insanoğluna yönelttiği sayısız hitabının olduğunu işaret eder. Bu hitaplarla ilgili peygamberin kavmine has birtakım emir ve yasakların yanında evrensel nitelikte bazı ilkelerin öğretildiği de malumdur. Bununla birlikte hangi kavme gelirse gelsin vahyin hukuki/şerî bakımdan tüm olayları konu edinmiş ve hepsi için hazır çözümler/hükümler sunmuş olması beklenemez. Bizatihi vahyin başı-sonu belli bir zaman dilimi içerisinde indirilmiş olması da bunu desteklemektedir. Zira Şâri' tarafından gelen her yeni hüküm, çözüme kavuşturulacak meselelerin henüz bitmediği gibi hiçbir zaman bitmeyeceğini de gösterir. Sonraki şeriatların öncekilerde yer alan bazı hükümleri neshettiği hususu da dikkate alındığında teşrî̀ tarihi boyunca gönderilen her bir hükmün genelgeçerlik vasfina sahip olmadığı dahası böyle bir gerekliliğin bulunmadığı anlaşılır.

Muhtelif zamanlarda gönderilen inşâi nitelikteki hitapların tüm meselelerin çözümünü ihtiva etmemesi Şâri'in kemal sıfatları ile birlikte düşünüldüğünde ilk bakışta sorunlu gözükebilir. Fakat bunun sorun teşkil edip etmemesi meseleye bakış açısıyla ilgilidir. Hitabın, muhatabın noksan sıfatları dikkate alınarak teşkil ve inzal edildiği dikkate alındığında bu sorun ortadan kalkmaktadır. Çünkü kıyamete kadar vuku bulacak her olayın bir benzeri vahyin indiği süreçte gerçekleşmemiştir. Haliyle bunların tek tek vahye konu 
edilmesi muhatap için hiçbir anlam ifade etmeyeceğinden ilahi hikmete de mugayirdir. Klasik dönemde müctehidlerin kahir ekseriyeti de konuya bu bilinçle yaklaştıklarından karşılaştıkları her meseleyi doğrudan çözen bir nassın bulunduğunu iddia etmemişler, nastan hareket edemedikleri durumlarda çözüme ulaşabilmek için çeşitli usulî enstrümanlar geliştirmişlerdir.

Klasik dönemde ortaya çıkan sorunların belki de en önemli özelliği sadelik ve süreğenliktir. Bu sebeple -teşekkül ve öncesi dönemleri paranteze alırsak- o dönemde fakihin ilk defa kendisinin karşılaştığı bir sorun genellikle bulunmaz. Çoğu defa mesele fakihten önce husule gelmiş, selef fukaha tarafından tartışllıp soruna dair çözümler ortaya koyulmuş ve konuyla ilgili büyük bir literatür oluşmuştur. Dolayısıyla ister yeni bir çözüm ortaya koysun ister mevcudu tekrar etsin bu dönemde fakih, seleflerinden bir miras devralabildiği için oldukça şanslıdır. Modern dönemde ise tam tersi bir durum söz konusudur. Teknolojik gelişmelerin etkisiyle karmaşık, hızla değişen ve geçmiştekilerle benzerlik arz etmeyen meselelerin sayısı hızla artmakta; fakih, bir taraftan karşılaştı̆̆ 1 sorunları tahlil etmekte zorlanırken diğer taraftan genellikle bu sorunlarla karşılaşan ilk kişi olmaktadır. Tabiatıyla klasikten farklı olarak modern fakih sadece nassın değil, seleflerinden devraldığı fıkıh birikimini taşıyan metinlerin de ihtiva etmediği birçok meseleyle karşı karşıya kalmaktadır.

Karşılaşılan sorunlardaki köklü yapısal farklılıklara rağmen klasik dönemde olduğu gibi modern dönemde de fakihin görevinde bir değişiklik yoktur. Zira ondan beklenen yoğun bir gayret sarf ederek derinlemesine kavrama faaliyetinde bulunması, akabinde karşılaşt1ğ1 mesele hakkında Şâri'in hükmünün ne olduğunu söylemesidir. Yalnız içtihat neticesinde bir yargıya varabilmesi için öncelikle fakihin/müctehidin zihninde varmaya çalıştığı yargının diğer bir ifadeyle "şerî hükmün" ne olduğuna dair bir tasavvurun bulunması gerekir. Çünkü o, bir taraftan nasların her bir meseleye dair hazır bir çözüm sunmadığını kabul etmekte diğer taraftan da her bir meselenin şer'î hükmüne ulaşmaya çalışmaktadır. Bu ise nass tarafından çözümlenmemiş meseleler için ortaya koyacağ1 çözümlerin meşrûiyeti/şer'îliği sorununu gündeme getirmektedir. Dolayısıyla müctehidin zihninde bu çözümleri de şerî̀ kılan bir hüküm tanımının bulunması gerekir. 
Hitabı anlamakla mükellef tutulan bizatihi akıl olduğuna göre şer'î hükme ulaşma hususunda aklın önünde ne gibi seçenekler olduğu önem arz eder. $\mathrm{O}$, ya her bir meselede nass bulunmadığını kabul edecek ya da doğrudan veya dolaylı olarak söylemediği şeyleri naslara söyletme yolunu tutacaktır. İkinci seçeneği tercih etmesi halinde akıl bir şekilde hükmü nassa söyletmiş gibi dursa da aslında haddini aşmış, "yorumda tahrif" kapsamına giren bir eylemde bulunmuş olur. Bu durumda şerî̀ hükme ulaşmak için aklın önünde "çözüm bekleyen vakıa üzerinde imal-i fikirde bulunarak hükme varmak" dışında bir seçenek kalmaz. Fakat bu seçenek, bildirim öncesinde eşya ve fiillere ait hasen ve kabih şeklinde bir takım vasıfların bulunduğunu ve aklın şer’̂̀ bildirimden bağımsız olarak bunları bilebileceğini kabul edenler için mevcuttur.

Anlaşılan o ki şerî̀ hüküm tanımı yapılmadan şer’̂̀ hükme varılması, aklın şerî hükme varma konusundaki yetki sahasını belirlemeden de şerî̀ hükmün tanımlanması olası değildir. Nitekim kurgusu Gazâlî tarafından yapılan mevcut yaygın şerî hüküm tanımında da buna dikkat çekilmiş fakat teolojik bir takım kaygılarla aklın yetki alanının son derece sınırlı olması yönünde tercihte bulunulmuştur. Ancak modern dönemde karşılaşılan ve nassın doğrudan ya da dolaylı olarak kapsamadığı meselelerin çözümü söz konusu olduğunda bu tercihin herhangi bir katkı sunmadığı çalışmanın ikinci bölümünde örnek meseleler üzerinden gösterilmeye çalışılacaktır. Fakat bunun tek ve zorunlu bir tercih olmadığ çok daha eski bir gelenek aklın yetki alanı ile ilgili tam tersi istikamette bir yaklaşım sergiler ki çalışmanın son bölümünde bu gelenek esas alınarak meselelerin çözümünde daha işlevsel olabilecek yeni bir hüküm tanımı teklif edilecektir. Ayrıca tanımın usulî katkıları ve ilgili olduğu meselelere kifayet miktarı değinilmeye çalışılacaktır. Yalnız bütün bunları yapabilmek için öncelikle aklın ve şer'̂̀/dinî hükmün doğrudan ilişkisi ve konuya temel teşkil etmesi bakımından aklın şer'̂̂/dini hükmü anlamadaki rolü üzerinde durmak gerekir.

\section{Dinî Hükmü Anlamada Aklın Rolü}

Sokrates (M.Ö. 399) yargılanmak için din işlerinden sorumlu yöneticinin sarayında bulunduğu sırada Euthyphron'la karşılaşır. Euthyphron, ırgatını öldüren babasını dava etmek için orada bulunmaktadır. Aslında baba katle mübâşeret etmemiş, verilecek cezayı öğrenene kadar hizmetçisini öldüren ırgatın elini ayağını bağ- 
layıp çukura atmıştır. Bu arada verilecek cezayı öğrenmek için birini tapınaktaki din adamlarına yollamıs, haber gelene kadar adamcağız açlık ve soğuktan ölmüştür. Babanın katil olarak nitelendirilemeyeceğini söyleyen ailenin tüm itirazlarına rağmen babasını mahkemeye verme konusunda kararlı olan Euthyphron Sokrates'e ailesinin dinî yasa (dindarlık) konusundaki kıt anlayışlılı̆̆ının kendisini hayrete düşürdüğünü söylemektedir. ${ }^{1}$

Platon'un Euthyphron adını verdiği meşhur diyalogda geçen gerçek dindarlığın ne olduğu hususundaki tartışma, Euthyphron'un babasına karşı cinayet davası açmasını dine uygun bir davranış olarak görmeyen ailesini kınamasıyla başlar. Özetle diyalogda Sokrates bir şeyin tanrılar tarafından sevilmesinin o şeyin bizâtihi dine uygunluk vasfina sahip olmasına bağlı olduğunu söyler. Buna göre dine aykırılık vasfına sahip olan şey de tanrılar tarafından sevilmeyecektir. Euthyphron ise tanrılar tarafından sevilip sevilmeme ile dine uygunluk ve aykırılık arasındaki ilişkinin bu şekilde gerçekleşmediğini savunur. Ona göre bir şeyin dine uygunluğunun o şeyde yer alan herhangi bir vasifla ilgisi yoktur. Zira dine uygunluğun yegâne ölçütü o şeyin tanrılar tarafından seviliyor olmasıdır. Tanrılar tarafından sevilmeyen şey de tabiatıyla dine aykırıdır. ${ }^{2}$

Karşılaştıkları meselelerin çözümünü din adamlarına sormak, "adalet" uğruna kişinin babasını mahkemeye vermesi ve hangi davranışın iyi, hangisinin kötü olduğuyla ilgili mezkûr kadim tartışmaya bakılırsa Tanrı/tanrıların rızasına uygun davranarak dini bütün biri olabilme gayret ve arzusu oldukça eskidir. Neyin dine uygun ya da aykırı kabul edilmesi gerektiği ile ilgili bu tartışma hiç şüphe yok ki günümüz ve konumuz açısından oldukça mühimdir. Zira tarafların meseleye bakış açıları ve konuya yaklaşım tarzları incelendiğinde aslında tartışmanın çok sonraları benzer şekilde İslam muhitinde de cereyan ettiği görülür. Çünkü tartışma, nihayetinde dine uygunluk ve aykırılığın eşyada mevcut bir takım vasıflarla ilgili olup olmadığ 1 hususundadır. Bu ise haddizatında dine uygunluk ve aykırılığın akılla bilinip bilinemeyeceğini tartışmak anlamına gelir.

Bilindiği üzere şer'î bildirim tarafından dine uygunluğu veya aykırılı̆̆ bildirilen şeylerin aynen kabul edilip muktezasınca amel

1 Platon, Euthyphron (Dindarlık Üzerine), çev. Güvenç Şar (İstanbul: Kabalcı Yayıncılık, 2011).

2 Geniş bilgi için bkz. Platon, Euthyphron (Dindarlık Üzerine). 
edilmesi gerektiği hususunda İslam bilginleri arasında bir ihtilaf yoktur. ${ }^{3}$ Ihtilaf, ilahi hitabın ulaşmadığ 1 coğrafyalarda ya da gelmediği dönemlerde aklın dine uygun ve aykırı olanları bilme yetisinin olup olmadığıyla ilgilidir. İlk etapta kelâmî bir tartışma hüviyetinde duran bu meselenin fikıh usulü ve fikıhla doğrudan ilişkisi göz ardı edilemeyecek derecede açıktır. Çünkü böyle bir mevzuda aklın rolü ile ilgili sergilenecek olumlu ya da olumsuz tavır, şer'î bildirim sonrasında hitaba konu olmamış meselelerle ilgili yaklaşımda da tayin edici bir rol oynayacaktır.

Şer'den bağımsız olarak aklın dine uygunluğu ve dine aykırılığı anlayabileceğini tartışmak aslında eşyada, onu dine uygun ya da aykırı kabul etmemize yarayan birtakım vasıfların olup olamayacağını tartışmaktır. İslam bilginlerinin kadim dönemlerde olduğu gibi bu konuda müspet (Mutezile/Mâtüridiyye) ve menfi (Eş'ariyye) olmak üzere iki yaklaşım etrafında kümelendiğini söyleyebiliriz. "Hüsün-kubuh aklî midir, değil midir?" şeklindeki temel soru etrafında dönen tartışmanın şerî bildirimin belirli bir tarihte son bulduğu ve sınırlı sayıda hazır çözüm ihtiva ettiği gerçeğiyle birlikte değerlendirilmesi gerekir. Çünkü nasların sayı ve kapsam bakımından sinırlılı̆̆ı, beraberinde aklın en azından bu sınırın ötesinde hareket kabiliyetinin olup olmadığı sorusunu gündeme getirmektedir. Gerçi nasların birden fazla anlama geleceği dolayısıyla gerçekleşebilecek her bir meselenin bu anlamlardan biri, değilse diğerinin kapsamına dahil edilerek çözümlenebileceği haliyle aslında nassın kapsamı için bir son sınırın olmadığ -kabul etmesek de- söylenebilir.

Tüm zamanlarda işlevsel kılabilmek ve bütün meselelere hazır çözüm olarak takdim edebilmek için nasların birden fazla anlama geldiğinin kabul edilmesi ilk anda kulağa hoş gelebilir. Fakat bunun kabul edilmesi halinde ilgili vakıayı çözüme kavuşturmak için hitabın anlamlarından hangisinin seçileceğinde sözün sahibinin değil, muhatabın tercihinin belirleyici olduğuna dikkat edilmelidir. ${ }^{4} \mathrm{Bu}$, tahrifin önündeki engelin tümden kaldırılması anlamına gelir ki nas

3 Dinî hükümlerin nihai kaynağı ve aklın bildirimden bağımsız dinî hükmü bilip bilemeyeceğiyle ilgili tartışma için bkz. Soner Duman, Fıkıh Usulünün Akli Temelleri (Şâfî̀ Usul Eserleri Çerçevesinde), ed. Ahmet Selman Baktı (İstanbul: Beka Yayıncılık, 2019), 141.

4 Dücane Cündioğlu, "Kur'an'ı Anlamanın Anlamı", 1. Kur'an Haftası Sempozyumu (Ankara: Fecr Yayınları, 1995), 184. 
ile vakıa arasındaki makasın daimî surette açıldığı ayrıca hesaba katılınca tek menfi durumun bu olmadığı görülür. Zira derinlemesine tahlil edilmeden vakıaya bir nas iliştirmek suretiyle ortaya konacak çözümlerdeki naiflik, sorgulayıcı zihinler tarafından hemen farkedilecektir. Buna rağmen her meselenin 1srarla, bir şekilde nas üzerinden okunup nastan hareketle çözüme kavuşturulmaya çalışılması yorumda tahrifin yanında -günümüzde de sıkça görüldüğü gibi- vakıanın içinde yaşayan bireylerin nastan uzaklaşmasına da sebep olacaktır.

İstihsan ${ }^{5}$, maslahat, sedd-i zerâi' ve örf gibi usulî enstrümanların bir yönüyle nassın kapsamına girmeyen meselelere çözüm üretmek üzere geliştirildiği söylenebilir. Fakat bizatihi bu delillerin hücciyeti/meşruiyeti üzerindeki tartışmalar dikkate alındığında bunlarla varılan çözümlerin nasıl şerî hüküm kapsamında görüleceği sorusu gündeme gelir. ${ }^{6}$ Şerî̀ hükme ulaşllırken bu yöntemlerin kullanılmasına karşı çıkan veya mesafeli duranların temel gerekçesi de budur. Örneğin istihsan konusunda İmam Şâfii'ye isnat edilen " من ş şeklindeki ibare ${ }^{7}$ bunu açık bir şekilde gösterir. İşte bu ve benzeri çekinceler/itirazlar usulcüleri "nassın bulunmadığ durumlarda hükme ulaşmak için kullandıkları yöntemlerin şer'îliği/meşruiyeti” ile ilgili ayrıca nas arama mecburiyetinde bırakmıştır. Zira yöntem nassa onaylatılabilirse ulaşılan çözüm fiilen şerî olacağından muhaliflerin itirazları geçerliliğini yitirecektir. Fakat ister yöntemin şer’̂liğine işaret eden nas bulunabilsin isterse de delil olarak sunulan nassın yöntemi işaret etmediği kesin bir şekilde ortaya çıksın müctehid bu yöntemi kullanmak mecburiyetindedir. Zira nas yetmemiş, vakıa bitmemiştir.

5 Burada (استحسان بالنص) değil örf, zaruret vb gerekçelerle nastan udûl edilmesi şeklinde icra edilen istihsanı kastetmekteyiz.

6 Bu soru hitabın şerî̀ hükme indirgenmesinin yol açacağı olumsuz sonuçları göstermek adına H. Yunus Apaydın tarafından "Hüküm Şâri'in hitabı olarak tanımlanınca müctehidlerin içtihat yoluyla ulaştıkları hüküm şerî̀ hüküm olarak nasıl nitelendirilebilir?" şeklinde sorulmuştur. Bkz. H. Yunus Apaydın, "Şerî̀ Hükmün Tabiatı", Modern Çağda Fıkhın Anlam ve İşlevi, ed. Osman Güman (İstanbul: Ensar Neşriyat, 2019), 75.

7 Gazâlînnin Şâfî̂̀ye nispet ettiği ibare "من استحسن فقد شرع" bu şekliyle Şâfirînin eserlerinde

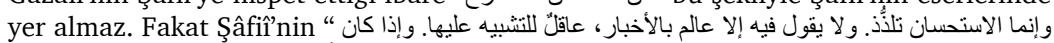

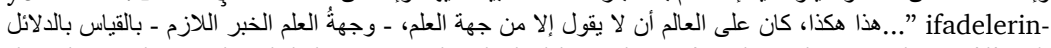
den bu anlam çıkarılabilir. Konuyla ilgili bkz. Ebu Hâmid Muhammed Gazâlî, elMüstesfâ, thk. Muhammed Abdüsselam (Beyrut: Dâru'l-kütübi'l-ilmiye, 1993), 171; Ebu Abdullah Muhammed b. İdrîs Şâfiî, er-Risâle, thk. Ahmed Şâkir (Misır: Mektebetü'l-halebî, 1940), 507. 
Karşılaştı̆̆ 1 meseleyi naslardan hareketle, onların kapsamına alarak $^{8}$ çözüme kavuşturamayan müctehidin, hangi yöntemi kullanırsa kullansın aslında yaptığı bizatihi vasıfları üzerinde akıl yürüterek Şâri'in ilgili meseledeki hükmünün ne olacabileceğini kestirmeye çalışmaktır. İçtihat meleke ve ehliyetine sahip olan müctehidin zihninde bu işlem çok doğal bir şekilde gerçekleştiğinden o takip ettiği yöntemlerin meşruiyeti için ayrıca bir delile ihtiyaç duymaz. Çünkü o vakıa hakkında ilk olarak naslarda hazır çözüm arar ve bulamayınca meselenin dine uygunluk ve aykırıllk yönlerini anlamak için fasıla vermeden düşünme faaliyetini sürdürür. Fakat bunun için müctehidin zihninde eşya üzerinde düşünüp hüküm vermeyi akıl için mümkün hâle getiren "eşyanın zatında hüsün ve kubuh vasıfları bulunur" şeklinde bir ön kabulün olması gerekir.

Eşyada hüsün-kubuh vasıflarının mevcudiyetinin ve aklen bilinebilirliğinin kabul edilmesi halinde şerî̀ hükmün bu vasıflarla ilişkisi bir başka sorun olarak görülebilir. Zira şer’î hüküm ya bunlara uygun ya da aykırı olacaktır. Aykırı gelebileceğini kabul etmemiz $186 \mid \mathrm{db}$ halinde Şâri'in mutlak adaleti, hep uygun gelmesi gerektiğini söylememiz halinde ise mutlak kudreti ile ilgili menfi bir durumla karşılaşırız. Çünkü şer'î hükümlerin eşyada mevcut olduğu var sayılan bu vasıflara muhalif bir şekilde gelmesi halinde Şâri'in hasen olmasına rağmen bir fiili yasaklaması yahut kabihliğine rağmen emretmesi ya da yapılmasına izin vermesi söz konusudur. Nasların her zaman bu vasiflarla uyumlu gelmesi gerektiği veya daha yumuşak bir ifadeyle hiçbir zaman bu vasıflara aykırılık teşkil etmeyeceği söylendiğinde de Şâri'in teşrî̀ faaliyeti birtakım ölçütlere tabi tutularak sınırlandırılmış olacaktır. Tam da bu sebeple Gazâlî eşyada hüsün-kubuh vasıflarının mevcudiyetini şiddetle reddeder. ${ }^{9}$ Böylece

8 Buradaki bütün akıl yürütmelerin meseleleri her zaman nastan bağımsız olarak çözmek anlamına gelmediğini kastetmekteyiz. Zira aklî bir yöntem olan fikhî kıyasta fer'in hükmü illet vasıtasıyla yine nastan elde edilir.

9 Geniş bilgi için bkz. Ahmet Selman Baktı, Şer'î Hükmün Tanımı ve Aslî İbâha İlkesi (Hanbelî Fıkhı Özelinde) (İstanbul: Kitâbi Yayınları, 2019). 
Allah'ın gerek yaratırken ${ }^{10}$ gerekse şer' vaz'ederken kudret sıfatına halel gelmemiş olur. ${ }^{11}$

Gerek tehâfütü'l-felâsifede nedenselliğin mümkün ve fakat zorunlu olmadığına ${ }^{12}$ gerekse el-Müstesfâ'da hüsün-kubuhun aklen bilinemeyeceğine ${ }^{13}$ dair izahatına bakıldı̆̆ında Gazâlînnin aklî istidlali oldukça üst düzeyde kullandığı görülür. Yalnız takdir edileceği üzere Gazâlî tarafından ortaya konulan bu istidlalin sağlamlığından bahsedebilmek için öncelikle aklın sahihi sakimden, doğruyu yanlıştan ve dahi haseni kabihten ayırabilecek yetide olduğunu kabul etmek gerekir. Haliyle aklın nassın kapsamına girmeyen meseleler üzerinde imal-i fikirde bulunarak hükme varabilme yeteneğine sahip bulunduğunun açık yüreklilikle kabul edilmesi gerekir. ${ }^{14}$ Zira aklın hükmü anlamada rolünün olmadığını ilmî kıstaslara uygun bir şekilde izah edebilmek için yine akıldan istimdat etmekten başka çare yoktur.

Öyle anlaşılıyor ki eşyadaki hüsün-kubuh vasıfları, nassın kapsamına girmeyen meselelerin çözümünde tayin edici bir rol oynayacaktır. Fakat bu vasıflardan hareketle varılacak hükmün meşruiyetinden bahsedebilmek için öncelikle şerî hükmün yeniden ve hüsün-kubuhun aklîliğini olumlayarak tanımlanması zaruret kesbetmektedir. Mehmet Erdoğan'ın her şeyin cevabının teşride aranıp tekvinin göz ardı edildiğini ${ }^{15}$ söylemesi bu anlamda önemlidir. Zira tekvin/mükevveni inceleyip yargıya varacak olan akıldır. Yine $\mathrm{H}$. Yunus Apaydın'ın şer'î hüküm tanımı konusundaki eleştirileri ve hükmü nassa indirgeyen mevcut klasik tanımdan hareket edilmesi halinde içtihatla varılan hükmün nasıl şerî̀ olarak nitelenebileceği-

10 Gazâlî ateşin pamuğu yakması gibi aralarında sebep-müsebbeb ilişkisi bulunduğuna inanılan "şey”ler arasındaki ilişkinin zarûrî/zorunlu olmadığını söyler. Bkz. Ebu Hâmid Muhammed Gazâlî, Tehâfütü'l-Felâsife, thk. Süleyman Dünyâ (Kahire: Dâru'lme’ârif, ts.), 237. Çünkü böyle bir şeyin kabul edilmesi yaratıcının fiillerini kısıtlama ve mucizeyi gayr-i mümkün kılma anlamına gelir. Bu yüzden o, hüsün-kubuhun akılla bilinebileceğini kabul etmez.

11 Ahmet Selman Baktı, "Vakıadan Hareketle Şer’î Hükme Ulaşmanın İmkanı (HüsünKubuh Nazariyesinin Kabulü veya Reddi)", Modern Çağda Fıkhın Anlam ve İşlevi, ed. Osman Güman (İstanbul: Ensar Neşriyat, ts.), 165.

12 Gazâlî, Tehâfütü'l-Felâsife, 237.

13 Gazâlî, el-Müstesfâ, 8, 45.

14 Ahmet Selman Baktı, "Vakıadan Hareketle Şerî Hükme Ulaşmanın İmkanı (HüsünKubuh Nazariyesinin Kabulü veya Reddi)", 165.

15 Mehmet Erdoğan, "Tebliğ Konusuna Katkı", Modern Çă̆da Fıkhın Anlam ve İşlevi, ed. Osman Güman (İstanbul: Ensar Neşriyat, 2019), 133. 
ne dair istifhâm-1 inkârîsi ${ }^{16}$ de bu konuda yeniden düşünüp bir şeyler söylemenin gerekliliği hususundaki vurgu ve tekliflerimizde haksız olmadığımızı gösterir.

\section{Mevcut Şer'î Hüküm Tanımı ve Modern Çağdan Birkaç Mesele}

F1kıh bilginlerinin karşılaştıkları bütün meseleler hakkında Şâri'in/şer'in hükmünü aramalarındaki temel gayenin "emre itaat ve nehiyden sakınma" kuralının her çağda sürdürülebilirliğini sağlamak olduğu söylenebilir. Çünkü hangi ekole mensup olursa olsun müctehitlerin son tahlilde amaçladıkları şey, dine uygun olanla olmayanı tefrik edip Şâri'in rızasına uygun davranmak ve dinin müntesiplerini bu hususlarda bilgilendirmektir. Haliyle onların da kadim dönemlerden beri süregelen tartışmada Sokrates'in yapmaya çalıştı̆̆ gibi bir meselenin hükmünü vermeden önce neyin dine uygun olup neyin olmadığına dair bir ön mülahazalarının olması gerekir. Şerî̀ hükmü araştırırken bu mülahazalarına uygun hareket etmeleri de bir diğer gerekliliktir. Zira şer’̂̀ hüküm netice itibarıla mükelleflerin fiillerinin dine uygun olup olmaması açısından kategorize edilmesinden başka bir şey değildir.

Esasa yönelik herhangi bir tartışma olmaksızın ${ }^{17}$ genel bir kabule mazhar olan hüküm tanımı "خطاب الثرع إذا تعلق بفعل المكلفين" şeklinde Gazâlî tarafından ve onun dine uygunluk konusundaki mülahazalarına mütenasip olacak şekilde kurgulanmıştır. $O$, dine uygunluk/aykırılık tasavvurunu Şâri'in mutlak kudreti üzerinden biçimlendirdiğinden naslardan bağımsız bir şekilde akılla anlaşılıp tayin edilebilecek bir "dine uygunluk/aykırılık yaklaşımını" asla kabul etmez. Hüküm tanımının fertleri arasına hitabu'ş-şer' ibaresini özenle koyarak hitabın mükellefin fiiline taalluk etmesiyle " إذا تعلق بفعل المكلف" şer̂̂ hükümden bahsedilebileceğine işaret etmesi bu yüzdendir. Böylece o, dine uygunluk ya da aykırıllığın şerî̀ bildirimden bağımsız bir şekilde akılla bilinebileceğini savunan bütün yaklaşımlara kapıyı net bir şekilde kapatır. Fakat burada biraz da şaşırtıcı

\footnotetext{
16 Apaydın, "Şer’î Hükmün Tabiatı", 75.

17 Hanefiler tarafından mezkûr tanıma "أثر” kaydı eklenmişse de bu, tanımda esaslı bir değişiklik yapmamıştır. Hüsün-kubuhun şer’iliği ve hükmün hitaba indirgenmesi üzerine kurulmuş bir tanımın, başına getirilecek "eser" kaydı ile hüsün-kubuhun aklîliğini olumlar hale gelmesi mümkün değildir. Bkz. Ahmet Selman Baktı, Şer'̂̂ Hükmün Tanımı ve Aslî İbâha İlkesi (Hanbelî Fıkhı Özelinde), 78.

18 Gazâlî, el-Müstesfâ, 45.
} 
olan şey Gazâlî̀nin mantığa dair mukaddimesinin hemen başında aklı azli mümkün olmayan bir hâkim, şer’i de tezkiye edilmiş bir şahit olarak nitelemesidir. ${ }^{19}$ Anlaşılan o ki Gazâlî̀nin tasavvur ettiği mahkemede hâkim hiçbir şeyi şahide sormadan karara bağlayamamakta dahası her ne sorarsa sorsun muhakkak şahitten bir yanıt alabilmektedir.

Gazâlı̂’nin şer’̂̀ hüküm tanımını onun dine uygunluk ve aykırılıkla ilgili tasavvuru, bu tasavvuru da müntesibi olduğu kelam ekolü belirler. Eş'arî kelam geleneğinin hüsün-kubuh konusundaki yaklaşımıyla ${ }^{20}$ Gazâlînnin yaptığı tanımı neden o şekilde kurguladığına dair izahlarına bakılarak bu durum kolayca teyit edilebilir. ${ }^{21}$ Her ne kadar ortaya konan tanıma ve tabiatıyla tanımı şekillendiren felsefi/teolojik arka plana katılmasak da yapılan tanım ile hüsün-kubuh konusunda ait olunan kelamî kimliğin çelişmemesi hususundaki özenli tutum takdire şayandır. Fakat bir fiilin dine uygun olup olmadığının akılla bilinebileceğini düşünenler Gazâli'nin tanımını benimsediklerinde özdeşlik/aynîlik ilkesini ihlal etmiş olacaklardır. Zira bu durumda onlar hem eşyada hüsün-kubuh vasıflarının olduğu ve bunun nas olmasa da akılla bilinebileceğini savunmakta hem de vahiy/nas olmaksızın hasen ve kabihin bilinemeyeceğini iddia etmektedirler.

Bilindiği üzere İmam Eş'arî̀ye göre Allah bir çocuğa azap edebilir ve bu onun adalet sifatına halel getirmez. Zira ona göre insanlar tarafından kabih olarak görülebilecek veya maşeri vicdanı yaralayabilecek tüm fiiller Allah tarafından gerçekleştirildiğinde hasen kapsamında değerlendirilir. ${ }^{22}$ Gazâlî’nin yaklaşımı da aynı minvaldedir. Ona göre dinî bildirim olmaksızın akıl, suçsuz birine acı çektirmek, yalan söylemek, nankörlük etmenin kötü/kabih/dine aykırı; doğru söylemek, nimete şükürde bulunmak, boğulmak üzere olan kişi/kişileri kurtarmanın da iyi/hasen/dine uygun olduğunu bilemez. Çünkü bunlardaki hasenlik ve kabihlik farklı durumlara nispetle değişkenlik arz edeceğinden zâtî değil, itibaridir. Bu sebeple neyin dine uygun/aykırı "hasen-kabih" olduğu sadece şerî bildirim-

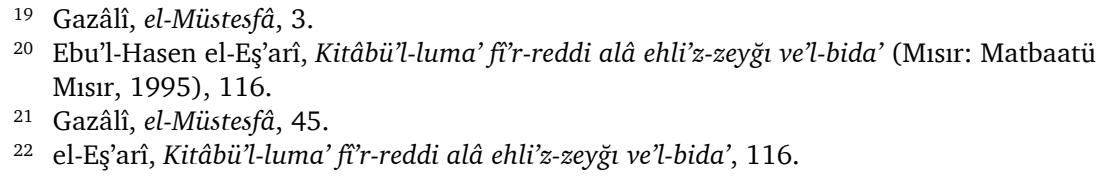


le tayin edilir. ${ }^{23}$ Isşte bu sebeple Gazâlî'den zikredilenden başka bir hüküm tanımı yapması beklenmemelidir.

Gazâlî̀nin yaptığı tanım onun karizmatik kişiliği ve Eş’arîliğin baskın rolüyle de birleşince neredeyse özsel hiçbir değişikliğe uğramadan tüm ekollerce kullanılmıştır. ${ }^{24}$ Fakat Mutezile ve Mâtüridiyye ekollerinin hüsün-kubuhun aklîliği konusundaki yaklaşımlarına bakılırsa şerî hükme akılla ulaşılabileceği konusunda Gazâlı̂’den farklı düşünenler hiç de az değildir. Fakat burada asıl üzerine düşünülmesi gereken husus, mevcut tanımın birazdan zikredilecek modern meselelerin çözümündeki işlevidir. Zira nassın doğrudan ya da dolaylı olarak söz söylemediği meselelerin kanaatimizce şer’̂̂ bildirim öncesinde ya da sonrasında gerçekleşmiş olması arasında bir fark bulunmaz. Bununla birlikte mevcut tanım bildirim öncesindeki meselelerin dine uygunluk ya da aykırılığı konusunda aklı açık ve kesin bir şekilde yetkisizleştirmektedir. Haliyle bu tarz meselelerin çözümünde mezkûr tanıma göre hareket edilmesi durumunda nasların, konuşmadıkları alanlarda kullanılması kaçınılmaz olacak$190 \mid \mathrm{db}$ tır. Bu nedenle hüsün-kubuhun aklîliğini savunan yaklaşımlar önemli hâle gelir.

Ölümcül hastalıkların erkenden engellenebilmesi, hamilelik öncesinde çocuğun cinsiyetinin belirlenebilmesi gibi birçok tasarruf gen teknolojisiyle artık mümkündür. Mesele imkân dairesinden çıııp vakıa haline geldiğinden batıda uzun bir süredir etik açıdan da ele alınmaya başlanmıştır. ${ }^{25}$ Almanya'da cinsiyet seçimi konusunda yapılan bir ankette "kız için pembe erkek için mavi bir hap içilerek gerçekleşebilecek kolaylıkta olsaydı çocuğunuzun cinsiyeti ile ilgili bir tercihte bulunur muydunuz?" şeklindeki soruya yer veri-

23 Gazâlî, el-Müstesfâ, 45.

24 Fahreddîn Ebu Abdullah Muhammed Râzî, el-Mahsûl, thk. Tâhâ Câbir Feyyâd (Beyrut: Müessesetü'r-risâle, 1997), 1, 89; Cemaleddin Osman İbnü'l-Hâcib, Muhtasaru müntehâ's-sûl ve'l-emel fî ilmeyi'l-usûl ve'l-cedel, thk. Nezir Hammad (Beyrut: Dâru ibn Hazm, 2006), 282; Muzafferüddîn İbnü's-Sâ'âtî, Bedîu'n-nizâm el-cem' beyne kitâbeyi'lPezdevî ve'l-İhkâm, thk. Sa'd b. Ferîd (Mekke: Câmi'atü Ümmü'l-Kurâ, 1985), 1, 138; Sadeddin Mesud b. Fahreddîn Ömer Teftâzânî, Şerhu't-Telvîh ale't-Tavdîh (Misır: Mektebetü sabîh, ts.), 1, 20; Muhammed b. Hamza Şemseddin Fenârî, Fusûlü'l-bedâ'î fî usûli'ş-şerâi', thk. Muhammed Hüseyin (Beyrut: Dâru'l-kütübi'l-ilmiye, 2006), 1, 261.

25 Julian Savulescu - Edgar Dahl, "Sex Selection and Preimplantation Diagnosis a Response to the Ethics Committee of the American Socity of Reproductive Medicine", Human Reproduction 15/ (2000), 1879-1880; John A Robertson, "Extending preimplantation genetic diagnosis: the ethical debate Ethical issues in new uses of preimplantation genetic diagnosis", Human Reproduction 18/3 (2003), 456-471. 
lerek tercihlerin toplumdaki erkek-kız cinsiyetinin oranını ne şekilde etkileyeceğine dair bilgi edinilmiştir. ${ }^{26}$ Ceza hukukuyla doğrudan ilgisi sebebiyle suçun tespiti konusunda teknik gelişmelerin göz ardı edilmesi artık mümkün değildir. ${ }^{27}$ Öte yandan organ naklinin mahiyet ve dini hükmü tam olarak vuzuha kavuşmamışken üç boyutlu yazıcılarla çeşitli organların üretilebilmesi üzerine çalışmalar oldukça başarılı bir şekilde sürmektedir. Bu meyanda Tel Aviv Üniversitesinde üç boyutlu yazıcıyla üretilen kalple ilgili makale ${ }^{28}$ bir taraftan tıpla ilgili mevcut gelişmelerin hangi aşamada olduğunu anlamamıza yardımcı olurken diğer yandan da yakın gelecekte olabilecekler hususunda önemli ipuçları vermektedir.

Kullanım alanlarının çeşitliliğini dikkate alarak yapay zekâ, sanal gerçeklik ve robot teknolojisi konusunda kaydedilen gelişmelere baktığımızda herhangi bir nas ile çözülemeyecek meselelerin gitgide arttığını kabul etmemiz gerekir. Sahibinin özelliklerini tanıyıp hoşlandığ şseyleri bilip ona göre davranan, sahibiyle duygusal hatta cinsel birliktelik kurabilen insansı robotlar özellikle gençlerin dikkatini çekmektedir. Satın alınıp kullanılmalarının, üretilmelerinin ya da daha ileri bir teknolojiye kavuşmaları için arge çalışmaları yapılmasının dinî hükmünün ne olduğunu -bunları cariye, köle ya da hür insana benzeterek- belirlemek bizce kabil ve doğru değildir. Ayrica bu ve benzeri meseleleri bir nassin kapsamına alarak hemen dinî hükmünü verme gayreti, çoğu defa meselenin felsefi, ahlaki ve teolojik açılardan tahlil edilmesinin önünde engel teşkil eder. Çünkü fakih, meseleyi nas kapsamına alarak "şerî hükme" bağlamanın rahatllğına erse de kısa bir süre sonra gayb, kader, ahlak ve özellikle yaratmayla ilgili sökün eden teolojik sorular karşısında hayrete düşebilir.

26 Bir hapla cinsiyetin tayini henüz söz konusu değildir. Fakat neticede cinsiyetin tayin edilebildiği bilindiğinden çalışma bunun çok kolay hale gelmesi durumunda tercihlerin ne olacağı üzerinde durmaktadır. Öte yandan çalışmada tercihlerin Almanya ölçeğinde kız-erkek cinsiyetindeki mevcut dengeyi çok olumsuz bir şekilde bozmayacağ 1 görülmüştür. Bkz. E Dahl vd., "Preconception sex selection for non-medical reasons: a representative survey from Germany", Human Reproduction 18/3 (2003), 2231-2234.

27 Adli tıpın delil değeri ile ilgili bkz. Şevket Pekdemir, İslam Hukukuna Göre Adli Tıp ve Maddi Delil (İstanbul: Nobel Akademik Yayıncılık, 2018); Bankacılıkla ilgili örnek bir problem için bkz. Şevket Pekdemir, İslâm Hukukunda Sözleşmelerde Cezâî Şart (İstanbul: Ensar Neşriyat, 2016).

28 Noor Nadav vd., "3D Printing of Personalized Thick and Perfusable Cardiac Patches and Hearts", Advanced Science 6/ (2019), 1-10. 
Son zamanlarda laboratuvar ortamında üretilen etler ${ }^{29}$ (labgrown meat/chiken) üzerine oldukça ciddi çalışmalar bulunmaktadır. Henüz yaygın bir şekilde market raflarında yerini almamış olsa da üretimi gerçekleştirilip insanlar tarafından yenme safhasını başaryyla geçmiştir. ${ }^{30}$ Üretiminin nasıl geçrekleştiği ${ }^{31}{ }^{31}$ tüketiciler nezdinde böyle bir ürünün kabul görüp görmeyeceği ${ }^{32}$ artan dünya nüfusunun beslenmesine katkıs1, ${ }^{33}$ konvansiyonel etlere bir muadil mi yoksa yeni bir besin mi olduğ $\mathrm{u}^{34}$ konuları çeşitli bilimsel çalışmalarda ele alınmaktadır. Basitçe anlatmak gerekirse laboratuvar ortamında elde edilen etlerin üretimi, gerekli gidanın hayvanlardan alınan hücrelere laboratuvar ortamında verilmesiyle gerçekleşir. Gıda alımı devam ettiği sürece bu hücreler canlı bir varlık olduğu için hayvan vücudunda olduğu gibi büyüyüp gelişmeye devam eder ve nihayetinde bir et kütlesi haline gelir.

Zikredilen meselelerin şer'î hükmü nedir sorusunun cevabını vermek kanaatimizce pek kolay değildir. Çünkü dikkatle bakıldığında bunlar hakkında kitap ve sünnetin herhangi bir hazır çözüm ihtiva etmediği rahatlıkla söylenebilir. Zira aksi iddia insanlığın ilk defa karşılaştığı bu örneklerin vahye konu edildiğini söylemek anlamına gelir ki bunun nasların sınırsız anlama geldiğini savunmadan kabul edilmesi mümkün değildir. Nasların sınırsız anlama geldiğini kabul etmekse hiçbir anlam ifade etmediğini söylemekle eşdeğerdir. İcmâ', Sahabe kavli, Amel-i ehl-i Medine, Şer'u men kablenâ veya örf gibi "kaynak" niteliği taşıyan usulî enstrümanların da zikredilen meseleler hakkında bir şeyler söylemiş olma ihtimali yoktur. Müttefekun aleyh bir "aklî yöntem" olan kıyas da işleyişi gereği bu ve benzeri meselelerin hükmüne ulaşmada kullanıla-

29 "Lab grown meat", "lab grown chicken", "in vitro", "cultured meat" ifadeleriyle tarayıcılarda yapılacak arama sonucunda birçok görsel malzeme ve akademik çalışmaya erişilebilir.

30 Laboratuvar ortamında elde edilen tavuk ve sığır etlerinin lezzet farkı olmadı̆̆ına dair bakınız "I tasted a lab-grown chicken nugget | Beta Test" (Erişim 13 Aralık 2020); "Tasting the World's First Test-Tube Steak" (Erişim 13 Aralık 2020).

31 Isam Kadım vd., "Cultured meat from muscle stem cells: A review of challenges and prospects", Journal of Integrative Agriculture 14/2 (2015), 222-233.

32 Christopher Bryan - Julie Barnett, "Consumer Acceptance of Cultured Meat: An Updated Review (2018-2020)", Applied Siences 10/ (2020), 1-25.

33 Sghaier Chriki - Jean François Hocquette, "The Myth of Cultured Meat: A Review", Frontiers in Nutrition 7/ (2020), 2-9.

34 Daniel Sergelidis, "Lab Grown Meat: The Future Sustainable Alternative to Meat or a Novel Func $\neg$ tional Food?”, Biomed J Sci \& Tech Res 17/1 (2019), 1244-12444. 
maz. ${ }^{35}$ Gittikçe artan buna benzer konuların çözümünde selef ulemadan tevarüs edilen eserlerin kaynak olarak kullanılamayacağı ise izahtan varestedir.

Öyle anlaşıllyor ki bu ve benzeri meselelerde istihsan, sedd-i zerâi', mesâlih-i mürsele veya son tahlilde aslî ibâha prensibinin işletilmesinden başka çare yoktur. Ne var ki bunlardan hangisi işletilirse işletilsin farklı "şerî hükümlere" varılabilecektir. Yalnız bu delillerin her birinin şer'î hükme ulaşmada kullanılmasının meşrû' olup olmadığ bulundurmak gerekir. Dolayısıyla bir fakihin zikrettiğimiz deliller vasıtasıyla varacağı hükmün başka bir fakih tarafından şerî̀ hüküm olarak görülmeyeceği de malumdur. Aslında açık söylemek gerekirse muhaliflerce meşru addedilmeyen bütün usulî deliller müctehidin veya tabilerinin bir şekilde nasla çözemediği meselelerin dine uygun olup olmadığına dair kendi kanaatlerini izah ederken kullandıkları kavramlardan ibarettir. Hemen söylemek gerekir ki bu kanaatlere müctehidi ulaştıran en temel vasıta ise akıldan başkası değildir. Dolayısıyla burada müctehidin vardığı sonuçların meşruiyetinin hüsün-kubuhun yani dine uygunluk ve aykırıllı̆ın sadece şer'î bildirimle değil, akılla da bilinebileceği ön kabulüne bağlı olduğu açık yüreklilikle kabul edilmelidir. Mevcut tanım böyle bir şeye imkân tanımadığından şerî̀ hüküm tanımının mezkûr içtihatlarla varılan hükümleri de içine alacak şekilde yeniden inşa edilmesi gerekir.

\section{III. Şer'î Hükü̈m Tanımının Yeniden İnşası ve Usulî Katkıları}

Sahih ile gayr-i sahih dini, beşer kelamı ile ilâhi kelamı ve neyin mucize neyin düzmece olduğunu anlayıp izah edecek olan tek yetkili merci akıldır. Bu nedenle -arkasındaki teolojik kaygılara ve Gazâlî tarafından bu kaygılar dikkate alınarak oluşturulmuş hüküm tanımına saygı duymakla birlikte- hükmün başka bir şekilde tanımlanmasını gerekli görüyoruz. Zira geride saydığımız güncel meselelerin hiçbirinde Gazâlî’nin metaforundaki hâkimin (aklın) şahitten (şer'den) alabileceği bir cevabın olduğunu veya olması gerektiğini düşünmüyoruz. Bununla birlikte metaforda yer aldığı gibi aklın

\footnotetext{
35 Nasların sınırlılığı sebebiyle kıyasın lüzumunun yanında kıyas ve yorumun da farklı şeyler olduğu hususunda bilgi için bkz. Soner Duman, "Modern Hukukta 'KıyasYorum İlişkisi'nin İslam Hukuku Açısından Değerlendirilmesi”, Hikmet Yurdu 5 (2010), 271-291.
} 
azledilemez bir hâkim şer'in tezkiye edilmiş bir şahit olduğuna yürekten katılıyoruz. Yalnız biz şahidin akıl tarafından tezkiye edildiğinin unutulmaması gerektiğini söylüyor, hakkında şahit bulunamayan fakat "hâkimin şahsi bilgisinin" olduğu meselelerin son zamanlarda mahkemeyi oldukça sık meşgul ettiğinin altını çiziyoruz.

Gazâlî tarafından ortaya konan şerî hüküm tanımı usul tarihine damga vurmuş olsa da yeni bir tanımın en azından denenmesi gerektiği açıktır. Yapılacak olan tanım elbette eşyada hüsün-kubuh özelliklerinin bulunduğunu ve aklın bunlardan hareketle dine uygunluk/aykırılık hakkında bir karara varabilme yetisine sahip olduğunu olumlamalıdır. Ancak bu tanım yeni olsa da tamamen "modern-çağdaş" ve tümüyle gelenekten kopuk olmak zorunda değildir. Teklif edeceğimiz tanım özelinde konuşmak gerekirse Mutezilî ve Matüridî geleneklerin teolojik kaygıları dikkate alınacağından bu tanımın kelâmî arka planını oluşturan kısmın köken itibarıyla Gazâlî'den ve intisap ettiği kelam geleneğinden çok daha öncesine uzandığını rahatlıkla söyleyebiliriz. Kelâmî arka planın ve tarihsel tecrübenin de dikkate alınması söz konusu olduğundan teklif edeceğimiz tanım yeni bir bakış açısı sunsa da ekol sistematiği içinde kalınarak meselelerin çözümüne önemli bir katkı sağlanacaktır. ${ }^{36}$

Mutezîle ve Mâtürîdiyye ekollerince eşyada hüsün-kubuh vasıflarının bulunduğu ve bu vasıfların aklen bilinebilir olduğu kabul edilir. ${ }^{37}$ Dolayısıyla onlara göre şer'in/nassın misyonu eşyada hasenliği veya kabihliği tayin etmek değil, mezkûr vasıfların üstündeki örtüyü kaldırmaktır. Haliyle her bir vakıanın hükmüne ulaşabilmek için nasla irtibat kurulamayacağının kabul edilmesi durumunda ${ }^{38}$ şer'î hüküm konusunda bir boşluk söz konusu olmayacaktır. Gerçi meselelere tikel naslarla çözüm bulunamaması halinde hüsün-

36 Ekol sistematiği kavramı için bkz. H. Yunus Apaydın, "Fıkhın Yenileşmesi ve Ekol Sistematiği”, İslam Fıkhının Dinamizmi Sempozyumu (Bursa: Kurav Yayınları, 2006), 71-76.

37 Mutezile ve Mâtürîliğin yaklaşımları için bkz. Ebu'l-Hasen b. Ahmed Kadı Abdülcabbâr, el-Muğnî, fì ebvâbi'l-adli ve't-tevhîd, thk. Muhammed Hadar (Beyrut: Dâru'lkütübi'l-ilmiye, 2012), 28; Ebu Mansûr Muhammed Mâtürîlî, Kitâbü't-Tevhîd, thk. Bekir Topaloğlu - Muhammed Aruççi (Beyrut: Dâru sadr, ts.), 304.

38 Geride saydığımız teknik gelişmelere bağlı meseleler de dahil olmak üzere her bir meselenin naslar kapsamına sokularak çözülmesi gerektiği aksi takdirde aklın Şâri' konumuna yüceltilmesi sorunuyla karşılaşılacağı söylenebilir. Fakat saydığımız meselelerin nasların kapsamına sokularak çözülmesi halinde bunu yapacak olanın yine akıl olacağı ve meseleye hangi nassın veya nasların tayin edileceğini yine aklın belirleyeceğini hatırlamak gerekir. 
kubuhun akli olmasına gerek olmadığı, genel nitelikli naslardan hatta şeriatın genelinden çıkarılacak prensiplerden hareket edilebileceği için zaten bir boşluktan bahsedilemeyeceği şeklinde itiraz gelebilir. Yalnız ilgili meseleyi genel nitelikli nasların kapsamına sokacak olanın yine müctehidin aklı olacağını göz ardı etmemek gerekir. Kaldı ki "Berâet-i zimmet asıldır", "Eşyada aslolan ibâhadır", gibi kritik öneme sahip prensiplerin dahi şeriatın genelinden çıkarıldığı hususunda peşin ve kesin hükümlü olunmamalıdır. Bunların dinî bildirimle çelişmediği ve dinî bildirimden hareketle de bu prensiplere ulaşılacağ 1 doğrudur. Fakat bu, mezkûr prensiplerin kaynağının dinî bildirim olduğunu değil, dinî bildirimin akılda mevcut olan bu kaideleri onadığını gösterir. ${ }^{39}$

Usulî fıkhın kelâmî kimlikle irtibatı ekseninde ele aldığımız şer’̂̂ hükmü başka bir çalışmada derinlemesine incelemiştik. Orada Muخطابُ اله تعالى المخلوقُ والكانثفُ عن الحسنِ و القبح مِن أفعالٍ المكلفين " tezile için "Allah'tn mükelleflerin fiillerindeki hüsün-kubuh vasıflarını açan/keşfeden ve bu vasıfların muktezasınca şekillenen hadis

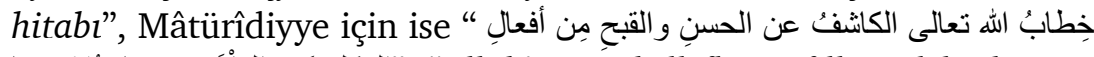
"Allah'in mükelleflerin fillerindeki hüsünkubuh vasıflarını açan/keşfeden ve bu vasıflara uygun olacak şeyleri gerektiren hitabı" şeklinde ayrı ayrı birer tanım önerisinde bulunmuştuk..$^{40}$

Fıkıh usulünün mensup olunan kelam ekolüne göre tayin edilmesi gerektiği aslında Alaaddin es-Semerkandî tarafından ısrarla vurgulanmış ${ }^{41}$ fakat bu çağrıya ders arkadaşı Lâmişî dışında bir karşılık veren çıkmamıştır. Benzer şekilde bizim özellikle güncel meselelerin çözümü hususunda önemli bir katkısı olacağını düşünerek yaptığımız tanım önerilerimiz de sadece Osman Güman tarafından takdir edilip dikkate alınmıştır. Güman sadece sorunu görüp tanım tekliflerinde bulunmamızı takdir etmekle kalmamış ayrıca Mutezile'nin teolojik kaygılarını dikkate alarak yaptığımız tanıma

39 Ahmet Selman Baktı, "Vakıadan Hareketle Şerî̀ Hükme Ulaşmanın İmkanı (HüsünKubuh Nazariyesinin Kabulü veya Reddi)", 170.

40 Bkz. Ahmet Selman Baktı, Şerî̀ Hükmün Tanımı ve Aslî İbâha İlkesi (Hanbelî Fıkhı Özelinde), 67-87. Mezkur hüküm tanımlarını 2012 yılında başladığımız "Hanbelî Fıkıh Geleneğinde İbâha-i Asliyye Prensibi" adlı doktora çalışmamızın ilk bölümünde teklif etmiştik. Hüküm tanımıyla ilgili müstakil bir bölümü ihtiva ettiğinden çalışmanın adını kitap olarak yayımlarken geride geçtiği şekilde değiştirdik.

41 Ebubekir Alaüddin Muhammed Semerkandî, Mîzânü'l-usûl fi netâici'l-ukûl, thk. Abdülmelik Abdurrahman (Mekke: Câmi’atü Ümmü’l-Kurâ, 1984), 2. 
katkıda bulunmuştur. O, tanımı "hitabın keşfettiği veya aklın idrak ettiği, mükelleflerin fiillerine ait zâtî bir vasıftır" " وصف ذاتي لأفعال " şeklinde düzenlemiştir. ${ }^{42}$ Böylece biz, aklın rolünü tanıma hüsün-kubuh üzerinden dercederken o, akıl lafzını doğrudan tanıma yerleştirmiştir.

Güman'ın da katkıda bulunduğu hüküm tanımları üzerinden hareket edildiğinde mantıksal çelişkiden kurtulma, güncel meselelerin çözümünde nasların yerli yerinde kullanılması ve naslarda yer alan hükümlerin doğru tespiti şeklinde üç önemli fayda elde edilecektir. Çünkü Eş'arîliğin hüsün-kubuh konusundaki olumsuz yaklaşımına uygun bir şekilde yapılan hüküm tanımı ile bir kısmı Mutezilî bir kısmı Mâtürîdî olduğu bilinen Hanefiler fikhi ameliyede bulunamaz. Fıkıh nihayetinde şer'i hükme ulaşma çabasını ifade ettiğinden mevcut hüküm tanımını esas alarak fikhî ameliyede bulunması Mutezili ve Mâtürîdi Hanefilerin yanında hüsün-kubuh konusunda onlar gibi düşünenleri özellikle de modern meselelerin çözümünde içine düşecekleri çelişkili durumdan kurtaracaktır.

Modern çağda fikhın ne gibi bir anlam ve işleve sahip bulunduğunun konunun uzmanları tarafından tartışılma ihtiyac1 ${ }^{43}$ tanımın ikinci olumlu katkısına güzel bir örnek teşkil eder. Nas-vakıa arasındaki içlem-kaplam münasebeti etrafında dönen bu tartışmanın özünde bir taraftan güncel meselelerin çözümünde nasların yerli yerinde kullanılmaması veya kullanılamaması, diğer yandan da içtihat ile varılan hükümlerin şerî kabul edilip edilememesi olduğu görülür. Burada bizce içtihat faaliyetinin mahiyeti sorgulanmalı ve bir karara varılmalıdır. Çünkü hükmün nassa/şer'e indirgenmesi halinde içtihat, meselenin bir şekilde nassın kapsamına sokulma çabasından başka bir mana ifade etmez. Bu durumda güncel meselelere çözüm üretirken çoğu defa naslar yerli yerinde kullanılamaz. Teklif ettiğimiz hüküm tanımı nasların sayı ve mana bakımından sınırlılığını esas alıp hükmün şer’̂̀ bildirime eşitlenmesini nefyettiğinden bu tanımdan hareket edilmesi durumunda nasların ilgili olmadıkları meselelere hamledilmesine ihtiyaç duyulmaz.

42 Osman Güman, Flkıh Geleneğinde Hukuk Felsefesi, ed. Ahmet Selman Baktı (İstanbul: Beka Yayıncılık, 2019), 61. Burada keşfetme ile mevcudun üzerini açma anlamı kastedilmektedir.

43 6-7 Nisan 2019 tarihinde Sakarya Üniversitesi İlahiyat Fakültesinde "Modern Çağda Fıkhın Anlam ve İşlevi” başlığıyla düzenlenen, alanın uzmanlarının iştirak ettiği tartışmalı ilmi ihtisas toplantısı böyle bir ihtiyacın mevcudiyetine dair güzel bir örnek olarak zikredilebilir. 
Tanımın yukarıda bahsettiğimiz üçüncü olumlu katkısı naslarda yer alan hükümlerin doğru tespitiyle ilgilidir. Tabi ki bu katkı da nihayetinde mantıksal çelişkiden kurtulma ve güncel meselelerin çözümünde nasların yerinde kullanılmasıyla irtibatlıdır. Fakat biz burada tanımın özellikle nasların anlaşılması esnasındaki içtihat faaliyetine yapacağı katkıyı kastediyoruz. Şöyle ki, malum olduğu üzere, Kitab ve Sünnet'te yer alan nasların delaletleri her zaman kat'̂̂ değildir. Delaletteki zannîlik bizzat ihtiva ettiği lafızlardaki bazı özellikler sebebiyle nastan çıkarılan anlamın muhkem veya müfesser seviyesine ulaşamamış olmasılyla gerçekleşebilir. Böyle durumlarda doğru anlamın tayininde bağlam bilgisi kilit bir role sahip olduğundan siyakın belirlenmesi hususuna yoğunlaşılması gerekir.

Umumun tahsisi, mücmelin beyanı, müşterek anlamlardan hangisinin esas alınacağı, delalet bahisleri ve benzeri birçok konuda siyak dikkate alınmadan çıkarılan anlamın kasd-ı ilâhi ile örtüştüğü söylenemez. Bu da nasta yer alan hükmün doğru şekilde tespitinin önünde büyük bir engel teşkil eder. Örneğin siga itibarıla umum bir lafız, tüm fertlerine şamil olabilirken sözü söyleyen bu lafızla tüm fertleri kastetmemiş olabilir. Böyle bir lafızla karşılaşılması durumunda hüküm vermek için kasıt araştırılacak yahut da lafzın umumu esas alınacaktır. İkinci seçenek tercih edildiğinde umum lafız doğrudan tüm fertlerine tatbik edilir. İlk seçenek ise mütekellimin kasdına dair bilgi edinmek için siyaka müracaat etmeyi icbar eder. Şâri' ile konuşmak veya vahyin indiği zamana gitmek mümkün olmadığından siyakı öğrenebilmek için zaman, mekân, muhatap ve benzeri bilgileri ihtiva eden rivayet malzemesine rücu etmekten başka çare yoktur.

İbn Dakîkü'l-îd tarafından "Konuşanın maksadının bilinmesini sağlayan metin içi ve dişı her türlü delâlet" şeklindeki siyak tanımına $^{44}$ ve siyakın maksadın anlaşılması hususundaki ehemmiyetine katılıyoruz. Fakat metin dışı karineleri öğrendiğimiz rivayetler sübut ve delaletlerindeki zannîlik sebebiyle bazen siyaka dair sağlıklı bilgi edinmemize imkân sağlayamayabilir. Bazen nassın anlaşılması için bağlama ihtiyaç olduğu halde zannî de olsa bağlamın bilinmesine yarayacak rivayetler bulunmaz. Böyle durumlarda tanımı ge-

44 Siyakla ilgili geniş bilgi için bkz. Osman Güman, "Siyak Kuralının Nasların Yorumuna Etkisi: İbn Dakîku'l-1̂d Örneği”, İslam Hukuku Araştırmaları Dergisi 21 (2013), 29-52. 
çen siyakın işlevselliğini yitireceği açıktır. Bununla birlikte hükme ulaşmak için kastı bilmeye olan ihtiyaç devam etmektedir. Haliyle fakih ya elindeki lafzın zahirine göre hüküm verecek ya da onu "anlamlı" hale getirecek bir bağlamı takdir edecektir.

Kurgusal bağlam “السياق الجعلي" şeklinde kavramsallaştırdığımız bağlamın takdir edilmesi meselesini devam eden bir çalışmada etraflıca incelediğimiz için burada ayrıntısına girmeyeceğiz. Bununla birlikte "kurgusal bağlam" hükmün tespiti için gerekli olan "siyakla" 45 aynı işlev ve öneme sahip olup ayrıca geride teklif edilen şer'î hüküm tanımı ile doğrudan irtibatlıdır. Şöyle ki doğru anlamın tespiti için siyak, siyak için de özellikle metin dışı rivayetlere ihtiyaç duyulur. Bizatihi bağlamda yer almaları sebebiyle ilk muhataplar hükmü ihtiva eden nasları (kitap-sünnet) her zaman esbâb-1 nüzul veya esbâb-1 vüruduyla birlikte aktarma ihtiyacı hissetmezler. Bu durumda kimi zaman hüküm içeren bir nas mevcut olmakla birlikte bu hükmün uygulanması halinde hüsün-kubuhun aklîliğini kabul edenler Şâri'in adaletine muhalif görülebilecek oldukça menfi durumlarla karşılaşabilir. Şerî hüküm hüsün-kubuh gereği adl-i ilâhi ile çelişmeyeceğinden onlar nezdinde hükmün doğru tespiti yapılamamıştır. Dolayısıyla hüsün-kubuh ve ilahi adalete uygun bir bağlam kurgulanmalidır.

Köpeklerin öldürülmesi konusunda nakledilen rivayetler zikrettiğimiz menfi durumlar için güzel bir örnek olabilir. Şöyle ki Hz. Peygamber köpeklerin öldürülmesini emreder. Bunun üzerine Abdullah b. Ümmi Mektûm evinin mescide uzak olduğunu, (görme engelli olup uzakta oturduğunu, geliş-gidişte köpeğinden yardım aldığını) köpeğinin öldürülmesi halinde mescide gelme hususunda müşkül duruma düşeceğini söyler. Bu mazereti dikkate alınıp kendisine ruhsat verilir fakat birkaç gün sonra diğerleri gibi onun köpeği de öldürülür. ${ }^{46}$ Bulunan her köpek öldürülmektedir. ${ }^{47}$ Öyle ki çölden Medine'ye gelirken (yol emniyeti için) yanlarında köpek bulunduran kadın ve kızların köpekleri dahi öldürülmüştür. ${ }^{48}$

45 Aslında bağlam/siyak ana başlık olmalı, rivayet vasıtasıyla bilinen ve fakih tarafından takdir edilen şeklinde iki kategoriye ayrılmalıdır. Bu durumda ilkini السباق الو اقعي, ikincisini de السياق الجعلي şeklinde adlandırabiliriz.

46 İbn Sa'd, et-Tabakâtü'l-kübrâ, thk. Muhammed Abdülkadir (Beyrut: Dâru'l-kütübi'lilmiye, ts.), 157.

47 Ebû Abdurrahman Ahmed Nesâî, Sünen (Beyrut: Müessesetü’r-risâle, 2001).

48 Ebü'l-Hasen İbnü'l-Haccâc Müslim, el-Cami'u's-sahîh, thk. M. Fuat Abdülbâkî (Beyrut: Dâru ihyâi't-türâsi'l-Arabî, ts.), 47. 
Köpek öldürme eylemi Medine ile de sınırl tutulmaz. Medine'nin etrafındaki yerleşim yerlerinde bulunan köpekleri öldürmek için de ekipler yollanır. ${ }^{49}$ Yaşlı bir kadın bu ekipteki görevlilerden birine insanlardan uzakta yaşadığını, köpeğinden başka kimsesi olmadığını, onun kendisini koruyup kolladığını ve köpeğiyle yalnızlığını giderdiğini Hz. Peygambere iletmelerini söyler. Gelen yanıt olumsuzdur, bu köpek de öldürülür. ${ }^{50}$ Hatta Hz. Peygamberin bu köpek de öldürülünce "şimdi rahatladım" dediği aktarılır. ${ }^{51} \mathrm{Ne}$ yazık ki rivayetler arasında köpeklerin katlini makul/makbul hale getirecek somut bir bağlam bilgisi bulunmaz.

İlgili rivayetlerden hareketle bugün de köpeklerin itlaf edilmesi naslara aykırı olmak bir tarafa mezkûr rivayetlerin bir gereği olarak görülebilir. Aklın yanı sıra ahlaki ve hukuki değerlere aykırı olduğu gerekçe gösterilerek bu rivayetlerin uydurma olduğu da öne sürülebilir. Yalnız sened bakımından herhangi bir sorun taşımayan bir rivayetin sırf bu gerekçelerle uydurma olduğu şeklindeki söylem akademik bir değer taşımaz. Zira bu yaklaşım ilahi hitabın anlaşılmasında sünnetin fonksiyonunu göz ardı etmek mecburiyetindedir. Çünkü malum olduğu üzere sünnetin kahir ekseriyeti sened bak1mından benzer özellikler taşır. Hâliyle bu mesele özelinde olumlu bir sonuç elde edilmiş gibi görünse de sünnetin sübutu ve işlevi esas alındığında mezkûr yaklaşım tarzının yol açacağı menfi durumlar ehlince takdir edilecektir.

Siyak bilgisine ulaşılamayan, aynen alınıp uygulanması yahut uydurma kabul edilmesine de imkân olmayan hüküm içerikli rivayetler için bir bağlamın kurgulanması kaçınılmazdır. Tabii ki kurgulanacak olan bu bağlam rastgele olmayıp bir taraftan Şâri'in adalet sıfatını gözetmeli diğer yandan da bu rivayetleri mevcut halleriyle koruma altına alabilmeli ayrıca naslar arasında (görünürde) bir çelişki varsa o çelişkiyi de ortadan kaldırabilmelidir. Türkiye'de köy ve kasabalara ekiplerin yollanıp insanların ellerinden kümes hayvanlarının alınıp gaz odalarına konularak öldürülmesi kuş gribi sebebiyle herkes tarafından makul karşılanmıştır. Mezkûr rivayetleri köpek kaynaklı olduğu bilinen ve gittikçe artan bir salgın şeklinde takdir edilecek bir bağlamla okuduğumuzda ne bir rivayetin ilgası-

49 Müslim, "Müsâkât, 45, 47.

50 Ebû Cafer Muhammed b. Cerîr Taberî, Camiu'l-beyân fî̀ tevîli'l-Kur'ân, thk. Ahmed Muhammed Şâkir (Beyrut: Müessesetü'r-risâle, 2000), 549.

51 Amr b. Bahr Câhız, el-Hayevân (Beyrut: Dâru'l-kütübi'l-ilmiye, ts.), 193. 
na gerek kalır ne de Şâri'in adalet sıfatına halel gelmiş olur. Ayrıca bazı naslar arasındaki çelişki de böylece ortadan kalkar.

Av köpeğinin dişlerini geçirdiği hayvanın etinin yenilebileceği Kitab ve Sünnet naslarıyla sabittir. ${ }^{52} \mathrm{~Hz}$. Peygamber hayattayken mescide köpekler girip çıkmakta hatta bevletmekte ancak ashâb bunu temizlemek için özel bir çaba harcamamaktadır. ${ }^{53}$ Başka su bulunmaması durumunda Atâ'nın teyemmüme gerek görmeyip köpeğin artığı olan su ile abdest alınabileceğini söylediği de bilinmektedir. ${ }^{54}$ Birlikte değerlendirildiğinde köpeğin içtiği veya yaladığ 1 kabın defalarca yıkanması emriyle ${ }^{55}$ bunlar arasında bir tearuz olduğu açıktır. Naslar arasındaki bu tearuzun diğerlerinden farklı olarak av köpeğinin eğitimli olmasıyla izahı mümkün değildir. Zira kabın yıkanması ile ilgili hadislerde av köpekleri istisna edilmez. Necasetin bir yıkamayla da giderilebileceği dolayısıyla köpeğin artığının veya yaladığı kabın yıkanma emrinin necislikle ilgili olmadığ da söylenmiştir. İbn Ömer ve Hasan-1 Basrîye göre kabın çok su harcanarak yıkanması emri yoldan geçenleri vs. korkuttuğu için $200 \mid \mathrm{db}$ köpek yetiştirmenin yasaklanmasıyla ilgilidir. Fakat yasağa rağmen insanlar köpek yetiştirmekten geri durmamıştır. Bunun üzerine kabın çok su harcanarak yıkanması emredilmiş, böylece su kıtlığı sebebiyle güç durumda kalacak olan insanların köpek yetiştirmekten vazgeçmesi amaçlanmıştır. ${ }^{56}$

"Gittikçe artan ve köpek kaynaklı olduğu düşünülen bir hastalığın mevcudiyeti" şeklinde teklif ettiğimiz bağlam takdir edildiğinde birçok sorun ortadan kalkar. Zira ruhsat verildikten sonra mazeret bildirenlerin köpeklerinin dahi öldürülmesi, köpeğin ağzını soktuğu kabın temizlenmesi için farklı zamanlarda farklı sayıda yıkamanın istenmesi, köpek besleyenlerin amellerinin bir veya iki Uhud dağı

52 Maide 5/4; Muhammed b. İsmail Buhârî, el-Cami'u's-sahîh (Dâru tavkı'n-necât, 2001), 175.

53 Buhârî, "Vudû", 174.

54 Buhârî, "Vudû", 169.

55 Köpeğin yaladığı veya artığı bulunan kabın üç kez veya bir kez toprakla ovmak üzere yedi ya da sekizinci toprakla ovmak kaydıyla yedi kez yıkanmasını emreden rivayetler için bkz. Ali b. Ömer Dârekutnî, Sünen (Beyrut: Dâru'l-ma'rife, 1966), "Tahâret", 196; Buhârî, "Vudû", 172; Müslim, "Tahâret", 89, 90, 91, 92, 93; Ebû İsa Muhammed b. İsa Tirmizî, Sünen, thk. Ahmed Muhammed Şâkir (Misır: Matbaatü Mustafa, 1975), "Tahâret", 91; Süleyman Ebû Dâvûd, Sünen, thk. M. Muhyiddin Abdülhamîd (Beyrut: Mektebetü'l-asriyye, ts.), "Tahâret", 71, 74.

56 Ebu'l-Hasen Ali b. Halef İbn Battâl, Şerhu sahîhi'l-Buhârî (Riyâd: Mektebetü'r-rüşd, 2003), 267. 
kadar $^{57}$ eksileceğ ${ }^{58}$ ve benzeri rivayetler bu bağlamla okunduğunda Şâri'in adaletini veya maşeri vicdanı zedelemez. Ayrıca bu rivayetlerle av köpeğinin dişlerini geçirdiği avın yenilebileceğini bildiren ayet arasındaki çelişki de ortadan kalkar. Çünkü salgının seyrine göre kişinin köpek beslerken mevcut amellerinden kaybedeceği sevap miktarının değişmesi, bütün köpeklerin itlaf edilmesi ve köpeğin yaladığı kabın hijyeniyle ilgili taleplerdeki değişiklikler son derece tabiidir. Ayrıca bu bağlamla okunduğunda av köpekleri ile ekin ve tarla bekleyen köpekler için verilen ruhsat ${ }^{59}$ da doğru anlaşlacaktır. Zira mevcut haliyle bu ruhsat diğer köpeklerin her zaman itlafını gerektirir. Oysa toplumsal hayatın idamesinde avcılık ve tarımın üstlendiği rol sebebiyle ruhsat, salgına rağmen zarurete binaen verilmiştir. Haliyle mevcut naslar salgın dışındaki bir zamanda köpek itlafını ya da köpek besleyenlerin kınanmasını gerektirmez.

\section{Sonuç}

Nasların bütün meseleler için hazır çözüm sunmadığı fukahanın kahir ekseriyeti nezdinde müsellemdir. Müsellemâttan olan bir diğer husus ise naslarda yer almasa da bütün meseleler için şerî̀ bir hükmün bulunduğudur. Bu iki kabul beraberinde usul eserlerinde özellikle de yöntem/menhec kategorisinde sayılabilecek aklî delillerin gelişmesine vesile olmuştur. Zira bu deliller büyük oranda nassın kapsamadığı meselelerin şer’̂̀ hükmüne ulaşmak için kullanılmaktadır.

Fıkıh faaliyetinin nihai amacı şer'î hükme ulaşmaktır. Bunun için fakih tabii olarak öncelikle ana kaynaklara (Kitâb-Sünnet) müracaat edecek, çözümü burada bulamaması halinde içtihat faaliyetini daha da yoğunlaştıracaktır. Modern çağa gelindiğinde çözümleri bu kaynaklarda yer almayan meselelerin sayısının gittikçe arttığı görülmektedir. Alanın uzmanları tarafından da çeşitli mahfillerde bu konunun ele alınması bir taraftan problemlerin artışını gösterirken diğer taraftan karşılaşılan meselelerin geçmiştekilerden farklı olduğuna işaret eder.

57 Kırat kelimesinin bir uhud dağı kadar sevâbı ifade ettiğine dair bkz. Buhârî, "Îmân", 47.

58 Bazı rivayetlerde bir bazılarında iki kırat eksileceği ifade edilmektedir. İlgili rivayetler için bkz. Buhârî, "Müzâra'a", 2323, 2324, "Bed'ü'l-halk" 3324, 3325, "Zebâih", 5480, 5481, 5482; Müslim, "Müsâkât", 50, 51, 52, 53, 54, 55, 56, 57, 58, 59, 60, 61.

59 Buhârî, "Zebâih", 5480; Müslim, "Müsâkât", 46. 
Fıkıh en nihayetinde karşılaştığı meselelere çözüm bulma istidadına sahiptir. Fakat çözümden önce fakihin zihninde bir çözümü neyin şer̂̂̀/meşru yapacağına dair sorunun cevaplanmış olması gerekir. $\mathrm{Bu}$ ise şer’̂̀ hükmün tanımı anlamına gelir ve yapılacak tanımlar aynı zamanda varılacak çözümlerde izlenecek yol ve yöntemlerde de belirleyici bir rol üstlenecektir. Usul literatürüne bakıldığında genel kabul görmüş tanımın Gazâlî tarafından oluşturulduğu görülür ki o haklı olarak tanımının efrâd/içsel ve ağyâr/dışsal unsurlarını belirlerken tümüyle Eş’arî kimliğini esas almıştır. Netice itibarıyla bu tanım, hüsün-kubuh konusunda aklın kesin bir şekilde devre dışı bırakılması temeline bina edilmiştir.

Hüsün-kubuhun şer' tarafından tayin edildiğini kabul etmeyenler nezdinde Gazâlînnin hüküm tanımıyla fıkıh faaliyeti yürütmek mümkün değildir. Zira bu tanım şerî hükmü ilahi hitaba eşitlemekte, aklın dinî bildirim olmaksızın şerî hükmü bilmesine imkân tanımamaktadır. Oysa Mâtürîdî ve Mutezilî kelam gelenekleri eşyada hüsün-kubuh vasıfları bulunduğunu ve bunların akıl tarafından anlaşılabileceğini kabul eder. Dolayısıyla bu geleneklere müntesip olan Hanefî fukaha nezdinde hüsün-kubuhun aklîliğini olumlayan başka bir hüküm tanımı bulunmalı, yoksa denenmelidir.

Modern çağda karşılaşılan ve benzerleri naslarda yahut fikıh müellefatında görülmeyen meselelerin, yapısı gereği mezkûr tanımla çözümlenmesi pek mümkün değildir. Zira bu tanımda hüküm hitaba indirgenmiş, hüsün-kubuhun aklîliği reddedilerek aklın meselelerin vasıflarından hareketle hükme ulaşması engellenmiştir. Bu durumda bu meseleler ya çözümsüz bırakılacak ya da bir şekilde naslarla irtibat kurularak çözümlenecektir. İkinci seçenek yorumda tahrife kapı aralayacaktır. Bu nedenle biz Mutezilî geleneği esas

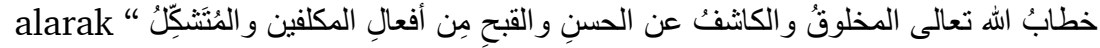

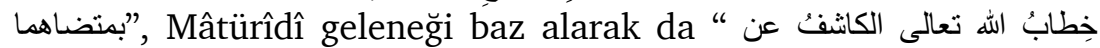

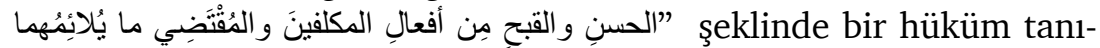
وصف ذاتي لأفعال " minı gerekli gördük. Güman tarafından yapılan "المكلفين يكثفه الخطاب أو يدركه العقل " hüküm tanımı ise aynı minvalde olup oldukça mühim bir katkı sağlamıştır.

Yapılan hüküm tanımları Hanefilerin kelâmî kimlikleriyle çelişmemeleri, nasların yerli yerinde kullanılması ve naslarda mevcut hükümlerin doğru tespiti şeklinde üç önemli fayda sağlar. Çünkü ilk olarak tanımda Hanefîlerin kelâmî kimlikleri esas alınmıştır. Karşılaşılan meselelerin çözümünde her zaman nasların kullanılamaya- 
cağını kabul ederek aklın hükmü anlamadaki rolünü vurguladığı için bu tanım esas alındığında benzeri bulunmayan meselelerin çözümünde nasla irtibat kurma zorunluluğu ortadan kalkar ve nasların ilgili olmadıkları yerde kullanılmasına gerek kalmaz.

Teklif edilen tanımın üçüncü önemli faydası ise mevcut naslarda yer alan hükümlerin doğru tespitine katkı sağlamasıdır. Zira tanım en nihayetinde hüsün-kubuhun aklîliğine yani Şâri'in adalet sıfatının akılla bilineceği tezi üzerine inşa edilmiştir. Naslarda yer alan kimi hükümlerin mevcut halleriyle uygulanması durumunda siyakın bilinmemesinden kaynaklı olumsuz sonuçlar elde edilebilir. Çünkü siyak sözün sahibinin sözle neyi kastettiğini bilmeyi sağlar. Siyakın bilinememesi halinde hüsün-kubuhun yani Şâri'in adaletinin akılla bilineceğini kabul edenler nas için adl-i ilâhiye uygun bir bağlam takdir edebilecektir.

\section{KAYNAKÇA}

Ahmet Selman Baktı. Şer'̂̂ Hükmün Tanımı ve Aslî İbâha İlkesi (Hanbelî Fıkhı Özelinde). İstanbul: Kitâbi Yayınları, 2019.

Ahmet Selman Baktı. "Vakıadan Hareketle Şer’̂̀ Hükme Ulaşmanın İmkanı (HüsünKubuh Nazariyesinin Kabulü veya Reddi)". Modern Çağda Fıkhın Anlam ve İşlevi. ed. Osman Güman. 157-176. İstanbul: Ensar Neşriyat, ts.

Apaydın, H. Yunus. "Şer'î Hükmün Tabiatı". Modern Çağda Fıkhın Anlam ve İşlevi. ed. Osman Güman. 65-75. İstanbul: Ensar Neşriyat, 2019.

arî, Ebu'l-Hasen el-Eş'. Kitâbü'l-luma' fìrr-reddi alâ ehli'z-zeyğı ve'l-bida'. Mısır: Matbaatü Misir, 1995.

Bryan, Christopher - Barnett, Julie. "Consumer Acceptance of Cultured Meat: An Updated Review (2018-2020)". Applied Siences 10/ (2020), 1-25.

Buhârî, Muhammed b. İsmail. el-Cami'u's-sahîh. Dâru tavkı'n-necât, 2001.

Câhız, Amr b. Bahr. el-Hayevân. Beyrut: Dâru'l-kütübi'l-ilmiye, ts.

Chriki, Sghaier - Hocquette, Jean François. "The Myth of Cultured Meat: A Review". Frontiers in Nutrition 7/ (2020), 2-9.

Cündioğlu, Dücane. “Kur’an’ı Anlamanın Anlamı”. 1. Kur'an Haftası Sempozyumu. 177217. Ankara: Fecr Yayınları, 1995.

Dahl, E vd. "Preconception sex selection for non-medical reasons: a representative survey from Germany". Human Reproduction 18/3 (2003), 2231-2234.

Dârekutnî, Ali b. Ömer. Sünen. Beyrut: Dâru'l-ma'rife, 1966.

Duman, Soner. Fıkıh Usulünün Akli Temelleri (Şâfî̀ Usul Eserleri Çerçevesinde). ed. Ahmet Selman Baktı. İstanbul: Beka Yayıncılık, 2019.

Duman, Soner. "Modern Hukukta 'Kıyas-Yorum İlişkisi'nin İslam Hukuku Açısından Değerlendirilmesi". Hikmet Yurdu 5 (2010), 271-291.

Ebû Dâvûd, Süleyman. Sünen. thk. M. Muhyiddin Abdülhamîd. Beyrut: Mektebetü'lasriyye, ts.

Erdoğan, Mehmet. "Tebliğ Konusuna Katkı”. Modern Çağda Fıkhın Anlam ve İşlevi. ed. Osman Güman. 132-150. İstanbul: Ensar Neşriyat, 2019.

Fenârî, Muhammed b. Hamza Şemseddin. Fusûlü'l-bedâ̂î fí usûli'ş-şerâi'. thk. Muhammed Hüseyin. Beyrut: Dâru'l-kütübi'l-ilmiye, 2006. 
Gazâlî, Ebu Hâmid Muhammed. el-Müstesfâ. thk. Muhammed Abdüsselam. Beyrut: Dâru'l-kütübi'l-ilmiye, 1993.

Gazâlî, Ebu Hâmid Muhammed. Tehâfütü'l-Felâsife. thk. Süleyman Dünyâ. Kahire: Dâru'lme'ârif, ts.

Güman, Osman. Fıkıh Geleneğinde Hukuk Felsefesi. ed. Ahmet Selman Baktı. İstanbul: Beka Yayıncilık, 2019.

Güman, Osman. "Siyak Kuralının Nasların Yorumuna Etkisi: İbn Dakîku'l-îd Örneği". İslam Hukuku Araştırmaları Dergisi 21 (2013), 29-52.

H. Yunus Apaydın. "Fıkhın Yenileşmesi ve Ekol Sistematiği". İslam Fıkhının Dinamizmi Seтроzуuтu. 71-76. Bursa: Kurav Yayınları, 2006.

İbn Battâl, Ebu'l-Hasen Ali b. Halef. Şerhu sahîhi'l-Buhârî. Riyâd: Mektebetü’r-rüșd, 2003.

İbn Sa'd. et-Tabakâtü'l-kübrâ. thk. Muhammed Abdülkadir. Beyrut: Dâru'l-kütübi'l-ilmiye, ts.

İbnü'l-Hâcib, Cemaleddin Osman. Muhtasaru müntehâ's-sûl ve'l-emel fí ilmeyi'l-usûl ve'lcedel. thk. Nezir Hammad. Beyrut: Dâru ibn Hazm, 2006.

İbnü's-Sâ'âtî, Muzafferüddîn. Bedîu'n-nizâm el-cem' beyne kitâbeyi'l-Pezdevî ve'l-İhkâm. thk. Sa'd b. Ferîd. Mekke: Câmi'atü Ümmü'l-Kurâ, 1985.

Kadı Abdülcabbâr, Ebu'l-Hasen b. Ahmed. el-Muğnî, fĩ ebvâbi'l-adli ve't-tevhîd. thk. Muhammed Hadar. Beyrut: Dâru'l-kütübi'l-ilmiye, 2012.

Kadım, Isam vd. "Cultured meat from muscle stem cells: A review of challenges and prospects". Journal of Integrative Agriculture 14/2 (2015), 222-233.

Mâtürîdî, Ebu Mansûr Muhammed. Kitâbü't-Tevhîd. thk. Bekir Topaloğlu - Muhammed Aruççi. Beyrut: Dâru sadr, ts.

204 | db Müslim, Ebü'l-Hasen İbnü'l-Haccâc. el-Cami'u's-sahîh. thk. M. Fuat Abdülbâkî. Beyrut: Dâru ihyâi't-türâsi'l-Arabî, ts.

Nadav, Noor vd. "3D Printing of Personalized Thick and Perfusable Cardiac Patches and Hearts". Advanced Science 6/ (2019), 1-10.

Nesâî, Ebû Abdurrahman Ahmed. Sünen. Beyrut: Müessesetü'r-risâle, 2001.

Pekdemir, Şevket. İslam Hukukuna Göre Adli Tip ve Maddi Delil. İstanbul: Nobel Akademik Yayıncilik, 2018.

Pekdemir, Şevket. İslâm Hukukunda Sözleşmelerde Cezâî Şart. İstanbul: Ensar Neşriyat, 2016.

Platon. Euthyphron (Dindarlık Üzerine). çev. Güvenç Şar. İstanbul: Kabalcı Yayıncılık, 2011.

Râzî, Fahreddîn Ebu Abdullah Muhammed. el-Mahsûl. thk. Tâhâ Câbir Feyyâd. Beyrut: Müessesetü'r-risâle, 1997.

Robertson, John A. "Extending preimplantation genetic diagnosis: the ethical debate Ethical issues in new uses of preimplantation genetic diagnosis". Human Reproduction 18/3 (2003), 456-471.

Savulescu, Julian - Dahl, Edgar. "Sex Selection and Preimplantation Diagnosis a Response to the Ethics Committee of the American Socity of Reproductive Medicine". Human Reproduction 15/ (2000), 1879-1880.

Semerkandî, Ebubekir Alaüddin Muhammed. Mîzânü'l-usûl fi netâici'l-ukûl. thk. Abdülmelik Abdurrahman. Mekke: Câmi'atü Ümmü'l-Kurâ, 1984.

Sergelidis, Daniel. "Lab Grown Meat: The Future Sustainable Alternative to Meat or a Novel Func $\neg$ tional Food?” Biomed J Sci \& Tech Res 17/1 (2019), 1244-12444.

Şâfiî, Ebu Abdullah Muhammed b. İdrîs. er-Risâle. thk. Ahmed Şâkir. Mısır: Mektebetü'lhalebî, 1940.

Taberî, Ebû Cafer Muhammed b. Cerîr. Camiu'l-beyân fí tevîli'l-Kur'ân. thk. Ahmed Muhammed Şâkir. Beyrut: Müessesetü'r-risâle, 2000.

Teftâzânî, Sadeddin Mesud b. Fahreddîn Ömer. Şerhu't-Telvîh ale’t-Tavdîh. Misır: Mektebetü sabîh, ts. 
Tirmizî, Ebû İsa Muhammed b. İsa. Sünen. thk. Ahmed Muhammed Şâkir. Mısır: Matbaatü Mustafa, 1975.

“I tasted a lab-grown chicken nugget | Beta Test". Erișim 13 Aralık 2020.

https://www.youtube.com/watch?v=S78YRBqZFik

"Tasting the World's First Test-Tube Steak". Erişim 13 Aralık 2020.

https://www.youtube.com/watch?v=bjSe-0vSRMY

$\mathrm{db} \mid 205$ 


\title{
Things Whose Provisions Are Not Found in The Qur'an And Sunnah And The Definition of The Shari'a's Judgment
}

\author{
Ahmet Selman BAKTI *
}

\section{Extended Abstract}

Even though al-Kitaab and as-Sunnah did not offer ready-made solutions for all the issues, there is a religious judgment regarding all issues. For this reason, Muslim jurists developed various mental evidences besides sources such as alKitaab and as-Sunnah. Because the ultimate aim of figh is to reach a religious decree. Therefore, the jurist will naturally heads to the main sources (KitaabSunnah) first, and if he cannot find a solution here, he will intensify his ijtihad activity. It is seen that the issues whose solutions are not included in these sources are increasing in the modern age in terms of number. The discussion of this issue in various circles by the experts of the field indicates the increase of problems on the one hand, and on the other hand, it indicates that the problems encountered are different from the previous ones.

Fiqh ultimately has the ability to find solutions to the issues it faces. But before a solution, the question of what makes a solution legitimate must be answered in the mind of the jurist. This means the definition of the religious provision, the definitions to be made will also play a decisive role in the ways and methods to be followed in the solutions to be reached. When we look at the history of Usul al- fiqh, it is seen that the generally accepted definition was created by Ghazali. He rightly took the Ash'ari identity as the basis when determining the internal and external elements of his definition. Consequently, this definition is based on the absolute disabling of the mind in the subject of Husn and Qubh.

For those who do not accept the designation of Husn-Qubh by the Sharia, it is not possible to engage in fiqh activities with the definition of al-Ghazali. This definition equates between religious judgment and divine discourse, and does not allow the mind to know a religious matter without a religious statement. However, similar issues encountered in the modern era are not found in the Qur'an or jurisprudence. Therefore, it cannot be solved by the definition mentioned above. To solve these issues, it must first be accepted that the mind is able to understand religious decree independently of religious pronouncement. Looking at the history of the Usul al-fiqhfundamentals of jurisprudence, it is noted that unlike Al-Ghazali, the doctrines of the Maturidi and Mutizilian words accept that there are qualities of Husn-Qubh in things and can be understood with reason. Since it is a contradiction for the two schools of thought to rely on the definition of al-Ghazali, another definition of Shari'a ruling that affirms the

\footnotetext{
Asst. Prof. Ahmet Selman BAKTI, Sakarya Universty Faculity Of Theology Basic İslamic Sciences Islamic Law, selman_bkt@hotmail.com, Orcid Id: https://orcid.org/0000-0002-0222-3051
} 
rationality of Husn and Qubh must be found by Hanafi jurists, and if not, a new definition must be tried. Since we did not find it, we have proposed in this article a suitable new definition for the two schools mentioned above.

The religious judgments we have made provide three important benefits: not contradicting Hanafis' theological identities, using "nosuus al-kitaab and asSunnah" appropriately, and accurately determining the present provisions in the "nosuus al-kitaab and as-Sunnah". Because, first of all, the theological identities of Hanafis were taken as basis in the definition. The definition emphasizes the role of reason in understanding judgment, acknowledging that "nosuus al-kitaab an as-Sunnah" cannot always be used in solving the issues encountered. For this reason, based on the definition we propose, the obligation to solve each issue/problem by "nosuus al-Kitaab and as-Sunnah" disappears. Thus, "nosuus al-Kitaab and as-Sunnah" do not need to be interpreted out of their meanings by using them where they are not relavant.

The third important benefit of the proposed definition is that it contributes to the correct determination of the religious judgments in "nosuus al-Kitaab and asSunneh". Because the definition is ultimately built on the rationality of HusnQubh, that is, the thesis that Shari's attribute of justice can be known by reason. If certain religious judgments in "nosuus al-Kitaab and as-Sunneh" are applied in their current form, negative consequences can be obtained due to the unknown context. Because the context allows you to know what the owner of the word means. If the contex is not known, only those who accept that the Husn-Qubh and of course the justice of the Shari can be known by reason will be able to appreciate the appropriate context required by the divine justice of the text.

Keywords: Mind, al-Husn-al-Qubh, Divine Revelation.

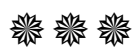

